\title{
Well Water Quality and Public Health Implications: the Case of Four Neighbourhoods of the City of Douala Cameroon
}

\author{
Epule Terence Epule (Corresponding author) \\ Institute of Environmental Sciences, University of Quebec at Montreal (UQAM) \\ Case postale 8888, succ Centre-Ville, Montréal (QC), H3C 3P8, Canada \\ Tel: 1-514-987-300 ext 3041 E-mail: epule.terence_epule@courrier.uqam.ca \\ Changhui Peng \\ Institute of Environmental Sciences, University of Quebec at Montreal (UQAM) \\ Case postale 8888, succ Centre-Ville, Montréal (QC), H3C 3P8, Canada \\ Tel: 1-514-987-3000 ext 1056 E-mail: peng.changhui@uqam.ca
}

Moto Wase Mirielle

Faculty of Medicine, Department of Public Health, Lund University

Box 117, SE-221 00 Lund, Sweden

Tel: 46-438-887-4884_E-mail mowamir@yahoo.com

Ndiva Mongoh Mafany

Sitting Bull College, Fort Yates, ND, USA

Tel: 1-701-8548-0517_E-mail: landysat@yahoo.com

Received: June 9, 2011 Accepted: June 27, 2011 doi:10.5539/gjhs.v3n2p75

This research is financed by the NSERC Canada discovery grant and the University of Buea that provided its microbiology laboratory for our analysis

\begin{abstract}
This paper analyses the quality of well water and population susceptibility to cholera outbreaks with respect to income levels in some neighbourhoods of the city of Douala Cameroon. Well water quality is degraded by faecal coliforms, this enhances out breaks of diarrhoeal diseases (cholera). Generally, the population is dominated by the poor who cannot afford pipe borne water, they resort to contaminated wells. To verify population perceptions of poverty and susceptibility to cholera, one hundred questionnaires were administered. To determine the presence of faecal coliforms in well water, forty well water samples were collected from the neighbourhoods. The statistical package for social sciences (SPSS) was used to analyse the data while the water samples were subjected to microbiological analysis. The results show that, the presence of bacterial agents like vibrio cholerea, sucrose fermenting and non sucrose fermenting organisms in well water poses great health threats in the study area.
\end{abstract}

Keywords: Faecal coliforms, Gram staining, Poverty, Vibrio Cholerae, Water quality, Wells 


\section{Introduction}

Water is one of the most important resources to man after air. An average human requires about 70 gallons of water daily. This includes water used for drinking, taken up in food, taking a bath, flushing toilets and general domestic sanitation inter alia (Recreational Boating and Fishing Foundation (RBFF), 2010). Ajaga, (2004), reaffirms the importance of water when he notes, "No one can ignore the fact that water is the source of life. Without it there can be no plants, no animals nor humans. The pattern of human settlements, the way of life of a people and their world view is often influenced by the quantity and quality of water at their disposal”. Therefore, if the planet earth has to be sustained, water has to be properly managed. Paradoxically, our global water resources are being degraded at a geometric rate and such degradations are anchored on anthropogenic sources (Acho-chi, 1998). The repercussions have been a kaleidoscope of public health problems with diseases such as cholera being rife.

The neighborhoods of Douala included in this study are Bepanda, Makepe, Nylon and Bonassama. Douala is the economic capital of Cameroon; this politico-economic qualifier has been due to the systematic growth of commercial and industrial complexes. It is a coastal wetland with huge amounts of water resources ranging from a myriad of sources amongst which are wells - the focus of this study, pipe borne water provided by the National water corporation now called Cameroon water corporation and numerous streams and rivers (Guevart et al., 2006; Ntaryike, 2004).

The daunting question now is why so much talk about water in Douala when water resources tend to be so "abundant"? However, it is the quality of water in Douala that raises the problem and not the quantity. To go by Coleridge's verse, "water water everywhere, not a drop to drink". This is tenable with the current study area as the sources of water are abundant yet the quality remains a salient constraint. The "roots" of the crisis are anchored in the fact that the city is a millionaire city with a population of about 3 million people (Lambi et al., 2001).

The issue of uncontrolled urbanization, proliferation of poor city new comers and the presence of almost 70000 urban wells is a call for concern (Guevart et al., 2006; Lambi et al., 2001). This huge population has led to the "mushrooming" of industries, slums and squatter settlements which lack basic amenities such as clean water for drinking but have several shallow and polluted wells which are also closely located by pit latrines (Guevart et al., 2006; Ntaryike, 2004). Wide scale land use and land cover changes as is the case of the study area will have vast effects on water quality and public health (Lambin et al., 2000). This view is supported by LeBlanc et al., (1996) when they note that land use changes affect the quality and quantity of water. As such, land use change has increased the surge in diarrheal and water borne diseases (Intergovernmental Panel on Climate Change, (IPCC), 2007; Mani et al., 2008; Yilla et al., 2010).

In the midst of this poor environmental sanitation picture, we find an antagonistic location of wells by latrines with a possible seepage of pollutants from the latrines into the wells being that the sub-stratum is that of a sedimentary basin (Todd, 1980; Dumort, 1968). Therefore, this paper will verify population perceptions of poverty and susceptibility to water borne diseases such as cholera as well as analyze well water samples to find out if the latter is host to pathogens that could cause water borne diseases such as cholera. To our knowledge, this is the first study that sample wells in Douala for microbiological and cholera analysis.

\section{Materials and methods}

\subsection{The study area}

The study area is part of the Douala sedimentary basin. It is found in the littoral Region of Cameroon and more specifically it covers Bonassama, Makepe, Bepanda and Nylon neighbourhoods of Douala (figure 1). These areas have been selected because they have been seriously affected by cholera and the entire city of Douala could not have been placed in the sample frame for reasons of costs.

Relatively, the Littoral Region is bordered to the North by the Western province, to the West by the South West Region, to the South by the Atlantic Ocean and the Southern Region and finally to the East by the Centre Region. Absolutely, Douala lies between longitudes $9^{\circ} 40^{\prime} \mathrm{E}$ and $9^{\circ} 50^{\prime} \mathrm{E}$ of the prime meridian and within latitudes $4^{\circ}$ $00^{\prime} \mathrm{N}$ and $4^{\circ} 54^{\prime} \mathrm{N}$ of the equator.

\subsection{Data collection}

To determine the population's perceptions of poverty levels judged by income levels and the vulnerability of the different income levels to cholera outbreaks, one hundred questionnaires were administered. Twenty five questionnaires were administered to each of the neighborhoods. The method of administering the questionnaires was purely random and the questionnaires were designed to address issues of income levels and the respondents' 
knowledge of susceptibility and experience with cholera. Administration of these questionnaires was done in January, 2006 (Williman, 2006; Bryman, 2004).

To determine water quality, forty well water samples were collected. Ten well water samples were collected from each of the neighborhoods. For each of the ten samples, five were collected in August, 2005 (rainy season) and five in January, 2006 (dry season). The temporal bias used in collecting samples in January, 2006 (dry season) was based on the premise that the area experiences wide scale water deficits at this time and pollution and recourse to unhealthy water sources is rife (Guevart et al., 2006; Mendelsohn \& Dawson, 2007). Those for the rainy season (August, 2005) were collected because wide scale floods had been reported responsible for depositing some pollutants from household sewage systems and latrines into wells (Guevart et al., 2006; Mendelsohn \& Dawson, 2007).

The samples were collected in $250 \mathrm{ml}$ sterile plastic containers. The containers were unscrewed at the well and a wedge to increase weight tied at the mouth of the container along with a rope that is about $25 \mathrm{~m}$ long. The rope and container were sent down the well and at water level the wedge descended the container into the well. Once the container was filled with water, the rope was pulled and the container was aseptically screwed, labeled and placed in an ice packed box for transportation. In the presence of ice the enzymes in the organisms become inactive and this kept them alive during transportation (Chakraborty, 1999; Cheesbrough, 1984; \& Cheesbrough, 2000). The samples were transported to the microbiology laboratory of the University of Buea, some 30 minutes from Douala.

\subsection{Data analysis}

The questionnaires were analyzed using the statistical package for social sciences (SPSS) version 19. This enabled the establishment of a relationship between poverty or income levels and population perceptions and experiences with cholera. This was done by coding the questionnaires to come out with different perceptions of the population with respect to income levels. After the coding, the data was entered into the software based on the created income groups or poverty levels. The software was then run to come out with the different trends.

At the laboratory the water samples were cultured in 20 test tubes (per sampling session) with alkaline peptone water (APW) at a $\mathrm{pH}$ of 8.6. The $\mathrm{pH}$ of 8.6 renders the medium selective for vibrio enrichment (Chakraborty, 1999). The culturing was done at room temperature of $37^{\circ} \mathrm{C}$ and this phase lasted for 24 hours. On the second day, incubates were further sub-cultured on Thiosulphate Citrate Bile Salt Sucrose agar (TCBS). All sub-culturing was done at $37^{\circ} \mathrm{C}$. The TCBS was prepared by diluting 8.8 grams of TCBS powder in $100 \mathrm{ml}$ water. The mixture was boiled at $100^{\circ} \mathrm{C}$ and allowed to cool down to $37^{\circ} \mathrm{C}$. The mixture was then poured on 20 Petri dishes (per sampling session), this was followed by the application of the alkaline peptone water broth (0.1 ml) on the sterile TCBS agar plates (Petri dishes). A sterile wire loop was used to streak the alkaline peptone water on the TCBS agar (streak method). The Petri dishes were now incubated at $37^{\circ} \mathrm{C}$ for 14 hours (Mendes et al., 2008).

The original color of the TCBS on the Petri dishes was blue but after the 14 hours incubation the isolates were observed to establish the presence or absence of large colonies of sucrose fermenting organisms (SFO) or Non sucrose fermenting organisms (NSFO). The observed patterns of growth after sub-culturing were as follows: + scanty, ++ moderate, +++ profuse. The colonies that harboured sucrose-fermenting organisms were yellow in color while those that had Non-Sucrose fermenting organisms were greenish in color (Mendes et al., 2008).

The isolates were now smeared on glass slides in thin films using a sterile wire loop or swab. The slides were allowed to dry and then the samples were fixed to the slides by passing the slides over the flames of a Bunsen burner. Precaution was taken so that the slides should not be too hot to hold. This is important because slides that are not properly fixed will be washed out during gram staining. During gram staining, crystal or gentian violet was applied and after 10 second it was washed under slow flowing water. Then, iodine was applied and after 10 seconds it was also washed under slow flowing water. The slides were carefully decolorized with $95 \%$ ethanol until the thinnest parts became colorless and later washed under slow flowing water. This was followed by the application of safranin and washed again after 10 seconds. At this point, the slides were allowed to dry at room temperature after which they were viewed under the microscope. Organisms that retained the violet iodine complexes appeared purple and were said to be gram positive while those that lost these complexes appeared pink after the counter staining with safranin and were equally gram negative.

From gram staining, colonies that had vibrio cholerae which causes cholera were gram negative, must have been greenish in color meaning NSFO had grown on them, were highly motile and oxidase positive (Cheesbrough, 1984). 


\section{Results}

Based on the 100 questionnaires that were administered this study has found out that there is a strong link between poverty levels represented as income levels and the number of people affected by water borne diseases such as cholera. In fact, when income levels are low the incidence of cholera is high whereas, the incidence of cholera decreases as income level increase (Figure 2).

As seen on figure 2, for the income group 5-20000 Francs CFA (French meaning: Coopération financière en Afrique centrale, English meaning: Financial Cooperation in Central Africa), 32 of the respondents report haven had an experience with cholera due to poor quality well water. In the case of the second income level that ranges from 21000-50000 Francs CFA, 15 respondents report haven had an experience with cholera. All subsequent income levels above 51000 Francs CFA do not report any cases of experience with cholera. Therefore, we can say that there is an inverse relationship between income levels and population susceptibility to water born diseases such as cholera. This is seen as the incidences of susceptibility to cholera outbreaks is higher for lower income groups and lower for higher income groups.

The results of the chemical analysis are presented in table 1, 2, 3 and 4 . Note that for each of the neighbourhoods, the first five samples were collected in the rainy season (August, 2005) while the last five were collected in the dry season (January, 2006).The temporal basis was applied to verify if variations would exist with changes in seasons. The results for Bepanda show that out of the ten wells sampled only sample eight that was collected during the dry season had vibrio that causes cholera. This sample equally had the presence of gram negative curved rod bacteria and the growth of non sucrose fermenting organism. However, the presence of gram negative rod in the other samples that are labelled non vibrio was an indication that the current non pathogenic organisms observed could revert to a pathogenic state. In Nylon, samples four and five (rainy and dry season samples) had vibrio. Just as in Bepanda, these samples were observed to have gram negative curved rod bacteria and experienced the growth of non sucrose fermenting organisms. These observed organisms where an indication that well water remains a deadly threat to health in this neighbourhood as the non pathogenic organisms can revert to a pathogenic state. In Makepe, non of the samples had vibrio. However, the presence of potentially pathogenic substances such as the gram negative rod organisms and all indicate a potentially deadly situation. Finally, in Bonassama, only sample four (rainy season sample) had vibrio; this sample equally had the presence of non sucrose fermenting organisms. Again, with the presence of the gram negative rod, this non pathogenic sample can revert to a pathogenic state. Generally, all samples that had vibrio also responded positively to the motility tests, had gram negative curved rod bacteria and had NSFO.

\section{Discussion}

This study has validated the hypothesis that there is an inverse relationship between income levels and population susceptibility to water borne diseases such as cholera. This view has been supported by Misselhorn, (2004), who notes that access to food and good quality water is often limited by poverty. Guevart et al., (2006) also notes that cholera in Douala has been endemic since 1971 and the main causes of this endemism are uncontrolled urbanisation dominated by poor city new comers who lack access to clean water. The notion here is that when people are poor their access to pipe borne water is limited. They resort to suspicious water found in shallow wells and urban streams that are highly polluted. This finding is also consistent with the conclusion of Mendelsohn \& Dawson, (2008) who observe that cholera is a disease that is not only propagated by poor sanitation but also by poverty.

Water remains a major source of spread of cholera and most other water borne diseases. Mintz \& Guerrant, (2009) confirm this when they argue that lack of safe drinking water can cause death. This view is consistent with views that water contaminated by either faecal coliforms or sewage could lead to cholera (Glass et al., 1991; Akoachere et al., 2008).

Looking at the seasonal variations of the potential outbreaks, we observe from our results that of the four samples that had vibrio cholerae, three were collected during the rainy season and one in the dry season. The rainy season results are consistent with results from other studies that hold that during the rainy season extreme rainfall can fill in sewage systems and this can in turn lead to wide scale seepage and flow of runoff into wells (Mendelsohn \& Dawson, 2008). Singh et al., (2001) argued further that there is a strong link between extreme rainfall and diarrhoeal diseases in Fiji. However, it can also be argued that the quantity of water available in an area during the dry season can also cause cholera outbreaks. This is so because at this time wide scale shortages of water cause the population to resort to doubtful sources of water. Inadequate rainfall can therefore lead to elevated incidences of cholera because of limited supplies of water; this is the reason why though the samples collected during the dry season show that just one well was fully positive for vibrio cholerae, such samples 
should be watched because they can easily revert to harbouring pathogenic strains of cholera (Mendelsohn \& Dawson, 2008). According to Fernandez et al., (2009) the cholera epidemic often begins with a rise in temperature in the dry season and peaks up during floods in the rainy season. The interactions between temperature changes and rainfall should be considered as factors that go together since they reinforce each other and make an already bad environmentally planned landscape a daunting one.

The well water samples collected and tested showed the presence of vibrio cholerae, non-vibrio, gram - Ve curved rod and gram - Ve rod bacteria. The general implication of these results is that the quality of well water is very low and the potentially pathogenic samples could revert to a pathogenic state. The low occurrences of Vibrio cholerae can be explained by the fact that the samples were collected during inter epidemic periods when there was a deprivation of food for the organisms and variations in $\mathrm{pH}$ and temperature. Thus, the culturing of potentially epidemic bacteria was limited by the fact that during such inter epidemic periods, traditional culture media or lack of techniques for the detection of a small number of cells of the viable non-culturable (VNC) vibrio makes it difficult to retrieve all vibrio from water ( Mendes et al., 2008). However, the methodology used in sampling these organisms remains the "gold standard for cholera diagnosis...." (Mendes et al., 2008). This is confirmed by Chakraborty et al., (1999) when they describe the application of alkaline peptone water followed by culturing on thiosulphate citrate bile salt sucrose agar and incubation as described in the methodology above.

\section{Conclusion}

Following the findings of this paper, it is possible that the wells in these neighbourhoods remain potential sources of cholera outbreaks. To make things worse, the poor masses with very low incomes are likely to be the essential precursor of any possible outbreaks. In August, 2011, nationwide outbreaks in poor neighbourhoods in Cameroon have proven this again. In this study, in spite of the fact that only four wells in total had vibrio cholerae, the presence of other substances such as sucrose fermenting organisms, non sucrose fermenting organisms, gram - and gram + bacteria all indicate that the water quality in the wells remain potential public health threats and sources of cholera outbreaks. It is important to state here that the observed level of occurrence of vibrio was because the samples were collected during an inter epidemic period. However, the methods used here remain very valid. This study recommends that municipal authorities should take action by enacting and implementing laws that will control the sitting of latrines, disposal of wastes, and provision of pipe borne water. The inhabitants should also be educated on common ways of avoiding cholera and treatment of water. In the area of research, this paper proposes that other large scale studies be carried out to verify some of the hypotheses made by this paper. Being that cholera continues to be a year in year out issue, this study calls on the government and municipalities to be implicated in salvaging the situation by making funds readily available for research.

\section{Acknowledgements}

We are thankful to the NSERC Canada discovery grant and the University of Buea that provided its microbiology laboratory for our analysis. Dr. Nkwelang Gerald assisted in the microbiological analysis. Thanks also go to Marline Mbinze Epule for providing lots of encouragements.

\section{References}

Acho-chi, C. (1998). Improved water Management systems in the Kano Closed settled zone: Problems and Possibilities. Journal of Applied Social Sciences, 1 (1), 49-98.

Ajaga, N. (2004). Why Poor People Remain Poor: Key Elements for Poverty Alleviation and Sustainable Development. (1st eds.). Yaoundé: Buma Kor, Cameroon (Chapter 1).

Akoachere, T. K., Oben, M. P., Mbivnjo, S. B., Ndip, M. L., Nkwelang, G., \& Ndip, R. N. (2008). Bacterial indicators of pollution of the Douala lagoon, Cameroon: Public health implications. African Health Sciences, 8 (2), 85-89.

Bryman, A. (2004). Social Research Methods. (3rd ed.). Oxford: Oxford University Press (Chapter 2, 3).

Chakraborty, S., Khanam, J., Takeda, Y., \& Nair, G. B. (1999). Application of PCR for detection of toxigenic Vibrio cholerae 01 in water samples during an outbreak of cholera. Transactions of the Royal Society of Tropical Medicine and Hygiene, 93, 527-528. http://dx.doi.org/10.1016/S0035-9203(99)90366-8

Cheesbrough, M. (2000). District Laboratory Practice in Tropical Countries Part II. (2nd ed.). Cambridge: Cambridge University Press (chapter 1.2, 3, 4).

Cheesbrough, M. (1984). Medical Laboratory Manual for Tropical Countries. (1st ed.). Linacre House, Jordan Hill Oxford: Educational Low Priced Books Scheme (chapter 1, 2, 3, 4, 5).

Dumort, J. C. (1968). Notice Explicative Sur le feville de Douala Ouest. Yaoundé Cameroon: Ministry of Mines. 
Fernandez, M. A. L., Bauernfeind, A., Jiménez, J. D., Gil, C. L., Omeiri, N. E., \& Guibert, D. H. (2009). Influence of temperature and rainfall on the evolution of cholera epidemics in Lusaka, Zambia, 2003-2006: analysis of a time series. Transactions of the Royal Society of Tropical Medicine and Hygiene, 103, 137-143. http://dx.doi.org/10.1016/j.trstmh.2008.07.017

Glass, R. I., Claeson, M., Blake, P. A., Waldman, R., Pierce, J., \& Nathaniel, F. P. (1991). Cholera in Africa: lessons on transmission and control for Latin America. The Lancet, Public Health, 338 (8770), 791-795. http://dx.doi.org/10.1016/0140-6736(91)9067-d

Guevart, E., Noeske, J., Solle, J., Essomba, J. M., Edjenguele, M., Bita, A., Mouangue, A., \& Manga, B. (2006). Factors contributing to endemic cholera in Douala, Cameroon. PubMed. gov (US National Library of medicine), National Institute of Public Health, 66 (3), 283-291.

Intergovernmental Panel on Climate Change (IPCC). (2007). Climate Change 2007. Synthesis report: An Assessment report Adapted by Section at IPCC Plenary. Contributions of working Group 3 to the $4^{\text {th }}$ Assessment report. [Online] Available: http://www.ipcc.ch/pdf/assessment-report/ar4/syr/ar4_syr.pdf (December 12, 2010)

Lambi, C. M., Fogwe, Z. N., \& Ndifor, F. (2001). Industrial Water Pollution: The Case of the Ndongbong Industrial District, Douala Cameroon. In C. M. Lambi (Ed.), Environmental Issues: Problems and Prospects, Bamenda, Cameroon: Unique Printers.

Lambin, E. F., Rounsevell, M. D. A., \& Geist, H. J. (2000). Are Agricultural Land-use models able to predict changes in land-use intensity? Agriculture, Ecosystems and Environment, 82, 321-331. http://dx.doi.org/10.1016/S0167-8809(00)00235-8

LeBlanc, R. T., Brown, R. D., \& FitzGibbon, J. E. (1997). Modelling the effects of land use change on the water temperature in unregulated urban streams. Journal of Environmental Management, 49, 445-469. http://dx.doi.org/10.1006/jema.1996.0106

Mani, M. M. A. \& Viju, I. (2008). Policy and institutional reforms to support Climate Change, Adaptation and Mitigation in Development programs. A practical guide. WDC: Environment Department, Sustainable Development Network, the World Bank.

Mendes, C. L., Coutinho, F. G., \& Leal, N. C. (2008). Development of a multiplex single-tube nested PCR (MSTNPCR) assay for vibrio cholera 01 detection. Journal of Microbiological Methods, 72, 191-196. http://dx.doi.org/10.1016/j.mimet.2007.11.018

Mendelsohn, J. \& Dawson, T. (2008). Climate and Cholera in KwaZulu-Natal, South Africa: The role of Environmental factors and implications for epidemic preparedness. International Journal of Hygiene and Environmental Health, 211, 156-162. http://dx.doi.org/10.1016/j.ijheh.2006.12.002

Mintz, E. D. \& Guerrant, R. L. (2009). A Lion in our Village - The Unconscionable Tragedy of Cholera in Africa. The New England Journal of Medicine, 360, 1060-1063. http://dx.doi.org/10.1056/NEJMp0810559

Misselhorn, A. A. (2004). What drives food insecurity in southern Africa? A meta-analysis of household economy studies. Global Environmental Change, 15, 33-43. http://dx.doi.org/10.1016/j.gloenvcha.2004.11.003

Ntaryike, D. (2004). New Cholera Cases on the Rise. The Herald. No 1502 Monday 17-18 may 2004. Yaoundé, Cameroon: Guardian Press.

Ntayike, D. (2004). Douala Cholera Epidemic Claims More Lives. The Herald, No 1510 Monday 7-8 May 2004, Yaoundé, Cameroon: Guardian Press.

Patz, J. A. \& Olson, S. H. (2008). Land use/Land change and Health. International Encyclopedia of Public Health, 15-21.

Singh, R. B., Hales, S., De. Wet, N., Hearnden, M., \& Weinstein, P. (2001). The influence of climate variation and change on diarrhoeal diseases in the Pacific Islands. Environ. Health Perspect. 109, 155-159. http://dx.doi.org/10.1289/ehp.01109155

Todd, D. K. (1980). Groundwater Hydrology. (2nd ed.). Canada: John Wiley and Sons (chapter 2, 4)

Recreational Boating and Fishing Foundation. (2010). Water, our most important resource. [Online] Available: http://www.takemefishing.org/general/credits (December 19, 2010)

Yilla, P. T., Kreuzinger, N., \& Nwetu, K. K. (2010). Temporal variability of two contrasting transient pollution events in a pastoral stream. Water Sciecnce Technology, 61(4), 1053-1063. http://dx.doi.org/10.2166/wst.2010.566

Williman, N. (2006). Social Research Methods. (2 ${ }^{\text {nd }}$ ed.). London: Saga Publications LTD (Chapters 1, 2, 3). 
Table 1. Colonial characteristics of Well Water after Culturing on TCBS for Bepanda

\begin{tabular}{|l|l|l|l|l|l|l|l|}
\hline $\begin{array}{l}\text { Wel } \\
\text { ls }\end{array}$ & \multicolumn{1}{|c|}{$\begin{array}{l}\text { Isolate } \\
\text { Identification }\end{array}$} & $\begin{array}{c}\text { Oxidase } \\
\text { Reaction }\end{array}$ & $\begin{array}{c}\text { Growth on } \\
\text { TCBS }\end{array}$ & $\begin{array}{l}\text { Growth } \\
\text { Pattern }\end{array}$ & Gram Reaction & $\begin{array}{l}\text { Motil } \\
\text { ity }\end{array}$ & \multicolumn{1}{c|}{$\begin{array}{l}\text { Putative } \\
\text { Organisms }\end{array}$} \\
\hline 1R & $\mathrm{BE}$ & - & $+\mathrm{Y}$ & +++ & Gram-Ve Rod & Non Vibrio \\
\hline 2R & $\mathrm{BE}$ & - & $+\mathrm{Y}$ & ++ & Gram-Ve Rod & - & Non Vibrio \\
\hline 3R & $\mathrm{BE}$ & - & $+\mathrm{Y}$ & +++ & Gram-Ve Rod & - & Non Vibrio \\
\hline 4R & $\mathrm{BE}$ & - & $+\mathrm{Y}$ & + & Gram-Ve Rod & - & Non Vibrio \\
\hline 5R & $\mathrm{BE}$ & - & $+\mathrm{Y}$ & +++ & Gram-Ve Rod & - & Non Vibrio \\
\hline 6D & $\mathrm{BE}$ & - & $+\mathrm{Y}$ & ++ & Gram-Ve Rod & - & Non Vibrio \\
\hline 7D & $\mathrm{BE}$ & - & $+\mathrm{Y}$ & +++ & Gram -Ve Rod & & Non Vibrio \\
\hline 8D & $\mathrm{BE}$ & - & $+\mathrm{G}$ & ++ & Gram-Ve Curved Rod & + & Vibrio \\
\hline 9D & $\mathrm{BE}$ & - & $+\mathrm{Y}$ & +++ & Gram-Ve Rod & & Non Vibrio \\
\hline 10D & $\mathrm{BE}$ & - & $+\mathrm{Y}$ & ++ & Gram-Ve Rod & & Non Vibrio \\
\hline
\end{tabular}

\section{Legend}

TCBS = Thiosulphate citrate bile salt sucrose agar, $+=$ Positive reaction, $-=$ Negative reaction, $\mathrm{Y}=$ Yellow colonies represent sucrose fermenting organisms, $G=$ Greenish colonies represent non sucrose fermenting organisms, $+=$ Scanty growth/ Motility, $++=$ Moderate growth, $+++=$ Profuse growth, $\mathrm{R}=$ Rainy season sample, $\mathrm{D}=$ Dry season sample, $-\mathrm{Ve}=$ Negative, $\mathrm{BE}=$ Bepanda

Table 2. Colonial Characteristics of Well Water after Culturing on TCBS for Nylon

\begin{tabular}{|l|l|c|c|c|c|c|c|}
\hline $\begin{array}{l}\text { Wel } \\
\text { ls }\end{array}$ & $\begin{array}{l}\text { Isolate } \\
\text { Identification }\end{array}$ & $\begin{array}{l}\text { Oxidase } \\
\text { Reaction }\end{array}$ & $\begin{array}{l}\text { Growth On } \\
\text { TCBS }\end{array}$ & $\begin{array}{l}\text { Growth } \\
\text { Pattern }\end{array}$ & Gram Reaction & $\begin{array}{l}\text { Mot } \\
\text { ility }\end{array}$ & $\begin{array}{l}\text { Putative } \\
\text { Organisms }\end{array}$ \\
\hline 1R & NY & - & $+Y$ & + & Gram-Ve Cocci in Chains & - & Non Vibrio \\
\hline 2R & NY & - & $+Y$ & ++ & Gram- Ve Cocci in Chains & - & Non Vibrio \\
\hline 3R & NY & - & $+Y$ & + & Gram-Ve Cocci in Chains & - & Non Vibrio \\
\hline 4R & NY & + & $+G$ & + & Gram-Ve Curved Rod & + & Vibrio \\
\hline 5R & NY & + & $+G$ & + & Gram-Ve Curved Rod & + & Vibrio \\
\hline 6D & NY & - & $+Y$ & ++ & Gram-Ve Rod & - & Non Vibrio \\
\hline 7D & NY & - & $+Y$ & +++ & Gram-Ve Rod & - & Non Vibrio \\
\hline 8D & NY & - & $+Y$ & ++ & Gram-Ve Rod & - & Non Vibrio \\
\hline 9D & NY & - & $+Y$ & + & Gram-Ve Rod & Non Vibrio \\
\hline 10D & NY & - & $+Y$ & +++ & Gram-Ve Rod & - & Non Vibrio \\
\hline
\end{tabular}

Legend

TCBS $=$ Thiosulphate citrate bile salt sucrose agar, $+=$ Positive reaction, $-=$ Negative reaction, $\mathrm{Y}=$ Yellow colonies, represent sucrose fermenting organisms, $G=$ Greenish colonies represent non sucrose fermenting organisms, $+=$ Scanty growth/ Motility, $++=$ Moderate growth, $+++=$ Profuse growth, $\mathrm{R}=$ Rainy season sample, $\mathrm{D}=$ Dry season sample, $-\mathrm{Ve}=$ Negative, $\mathrm{NY}=$ Nylon 
Table 3. Colonial characteristics of Well Water after Culturing on TCBS for Makepe

\begin{tabular}{|l|l|l|l|l|l|l|l|}
\hline Wells & $\begin{array}{l}\text { Isolate } \\
\text { Identification }\end{array}$ & $\begin{array}{l}\text { Oxidase } \\
\text { Reaction }\end{array}$ & $\begin{array}{l}\text { Growth } \\
\text { on TCBS }\end{array}$ & $\begin{array}{l}\text { Growth } \\
\text { Pattern }\end{array}$ & Gram Reaction & $\begin{array}{l}\text { Motilit } \\
\mathrm{y}\end{array}$ & $\begin{array}{l}\text { Putative } \\
\text { Organisms }\end{array}$ \\
\hline 1R & MA & - & + Y & +- & Gram-Ve Rod & + & Non Vibrio \\
\hline 2R & MA & - & $+Y$ & +++ & Gram-Ve Rod & + & Non Vibrio \\
\hline 3R & MA & - & $+Y$ & +- & Gram-Ve Rod & + & Non Vibrio \\
\hline 4R & MA & - & $+Y$ & - & Gran-Ve Rod & + & Non Vibrio \\
\hline 5R & MA & - & $+Y$ & +- & Gram-Ve Rod & + & Non Vibrio \\
\hline 6D & MA & - & $+Y$ & ++ & Gram-Ve Rod & + & Non Vibrio \\
\hline 7D & MA & - & $+Y$ & +++ & Gram-Ve Rod & + & Non Vibrio \\
\hline 8D & MA & - & $+Y$ & ++ & Gram- Ve Rod & + & Non Vibrio \\
\hline 9D & MA & - & $+Y$ & - & Gram-Ve Rod & + & Non Vibrio \\
\hline 10D & MA & - & $+Y$ & ++ & Gram-Ve Rod & + & Non Vibrio \\
\hline
\end{tabular}

Legend

TCBS $=$ Thiosulphate citrate bile salt sucrose agar, $+=$ Positive reaction, $-=$ Negative reaction, $\mathrm{Y}=$ Yellow colonies represent sucrose fermenting organisms, $G=$ Greenish colonies represent non sucrose fermenting organisms, $+=$ Scanty growth/ Motility, $++=$ Moderate growth, $+++=$ Profuse growth, $\mathrm{R}=$ Rainy season sample, $\mathrm{D}=$ Dry season sample, $-\mathrm{Ve}=$ Negative, $\mathrm{MA}=$ Makepe

Table 4. Colonial characteristics of Well Water after culturing on TCBS for Bonassama

\begin{tabular}{|l|l|c|l|l|l|l|l|}
\hline Wells & $\begin{array}{l}\text { Isolate } \\
\text { Identification }\end{array}$ & $\begin{array}{l}\text { Oxidase } \\
\text { Reaction }\end{array}$ & $\begin{array}{l}\text { Growth on } \\
\text { TCBS }\end{array}$ & $\begin{array}{l}\text { Growth } \\
\text { Pattern }\end{array}$ & $\begin{array}{l}\text { Gram } \\
\text { Reaction }\end{array}$ & Motility & $\begin{array}{l}\text { Putative } \\
\text { Organism }\end{array}$ \\
\hline 1R & BO & - & $+\mathrm{Y}$ & +++ & Gram-Ve Rod & + & Non Vibrio \\
\hline 2R & BO & - & $+Y$ & ++ & Gram-Ve Rod & - & Non Vibrio \\
\hline 3R & BO & - & $+Y$ & + & Gram-Ve Rod & + & Non Vibrio \\
\hline 4R & BO & + & + G & ++ & $\begin{array}{l}\text { Gram-Ve } \\
\text { Curved Rod }\end{array}$ & + & Vibrio \\
\hline 5R & BO & - & $+Y$ & + & Gram-Ve Rod & + & Non Vibrio \\
\hline 6D & BO & - & $+Y$ & +++ & Gram-Ve Rod & + & Non Vibrio \\
\hline 7D & BO & - & $+Y$ & --+ & Gram-Ve Rod & + & Non Vibrio \\
\hline 8D & BO & - & $+Y$ & + & Gram-Ve Rod & + & Non Vibrio \\
\hline 9D & BO & - & $+Y$ & +- & Gram-Ve Rod & + & Non Vibrio \\
\hline 10D & BO & - & $+Y$ & +++ & Gram-Ve Rod & + & Non Vibrio \\
\hline
\end{tabular}

Legend

TCBS $=$ Thiosulphate citrate bile salt sucrose agar, $+=$ Positive reaction, $-=$ Negative reaction, $\mathrm{Y}=$ Yellow colonies represent sucrose fermenting organisms, $G=$ Greenish colonies represent non sucrose fermenting organisms, $+=$ Scanty growth/ Motility, $++=$ Moderate growth, $+++=$ Profuse growth, $\mathrm{R}=$ Rainy season sample, $\mathrm{D}=$ Dry season sample, $-\mathrm{Ve}=$ Negative, $\mathrm{BO}=$ Bonassama 


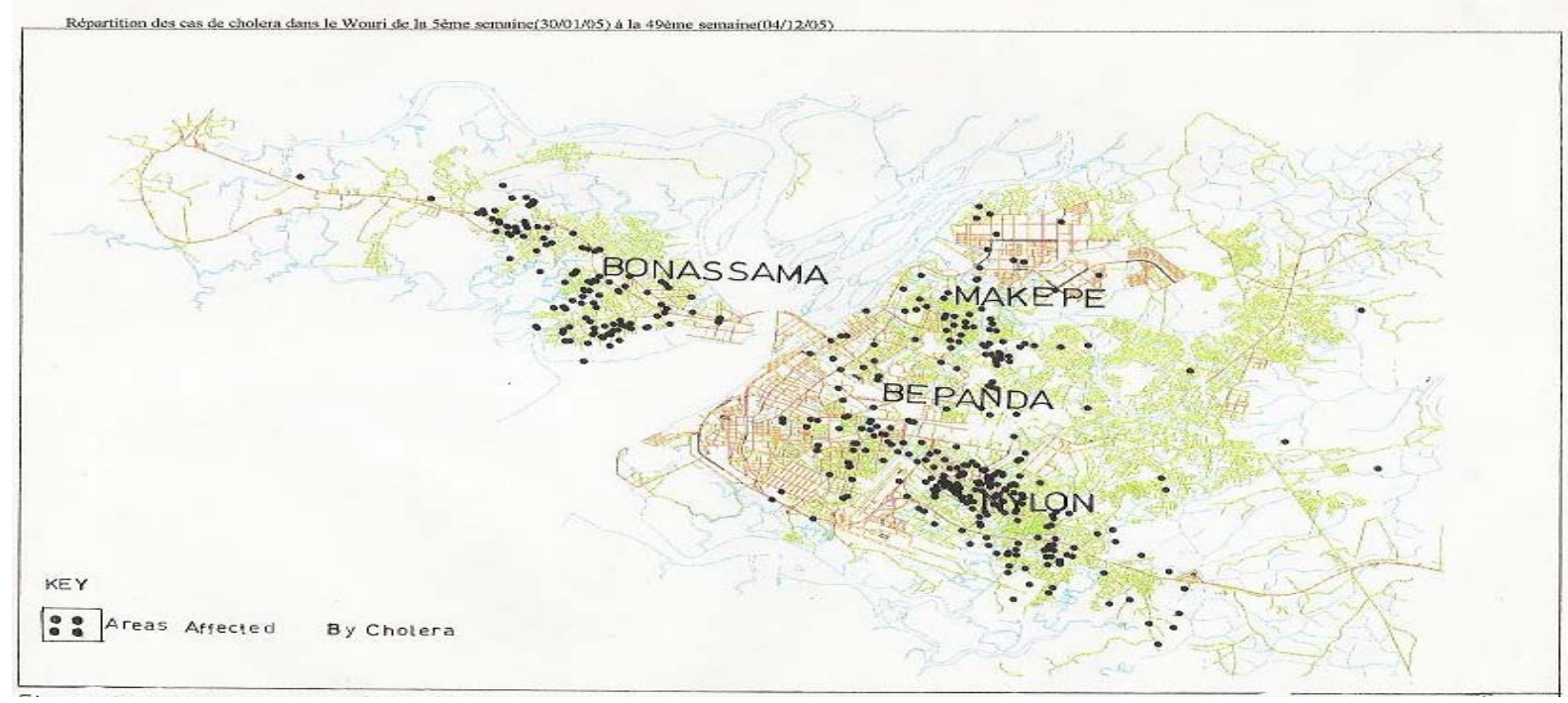

Source: Modified from GTZ Health Project Doula (December, 2005)

Figure 1. Partitioning of cases of cholera in Doula from 30 January 2005-4 December 2005. The four neighbourhoods included in the study are Bepanda, Makepe, Bonassama and Nylon

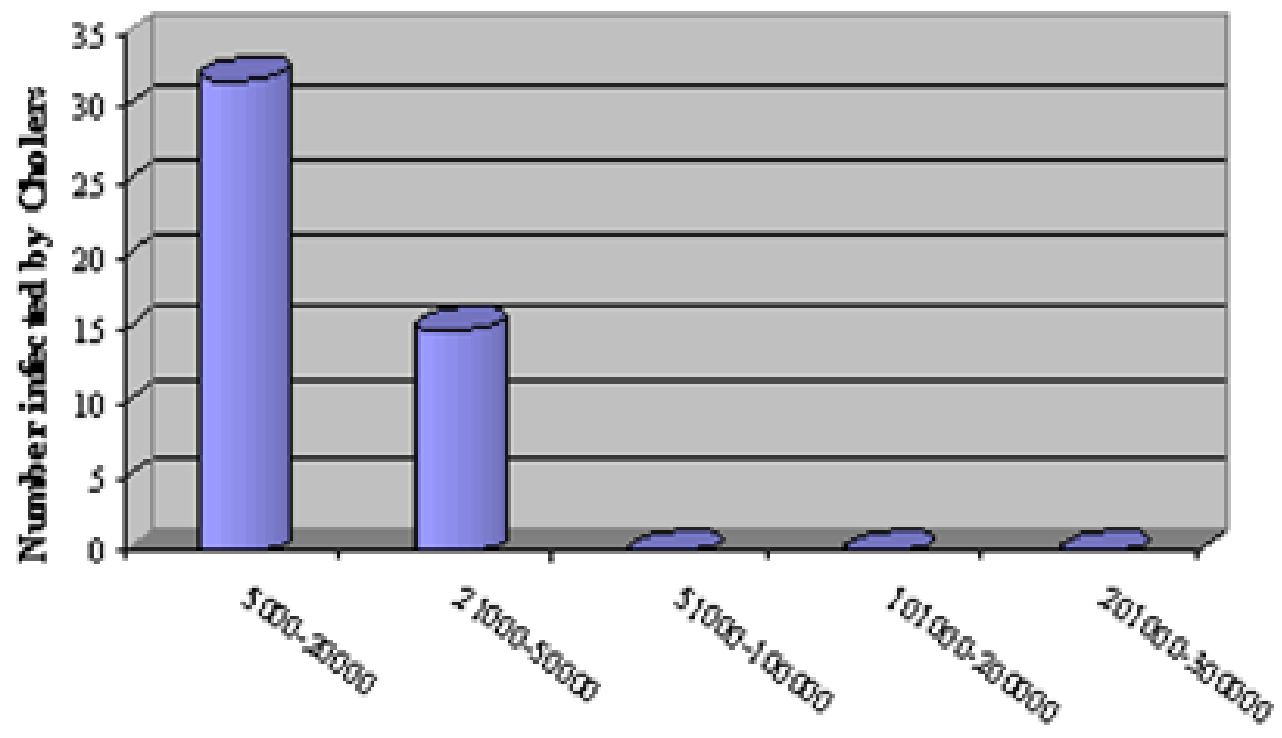

Income/Poverty levels in CFA francs

Figure 2. Perceptions of the relationship between poverty and the number of people affected by cholera. Figure suggest that the lower the incomes the higher the occurrence of cholera outbreaks and vice versa. Income levels are measured by the currency used in Cameroon CFA (French: Coopération financière en Afrique centrale, English: Financial Cooperation in Central AfricaFrancs). 